Jurnal Pemikiran Sosiologi Volume 5 No. 2, Agustus 2018

\title{
Pemberdayaan Masyarakat Berbasis “Social Entrepreneurship” Bidang Pertanian dan Peternakan: Studi Kasus Desa Bukit Langkap Kabupaten Lingga, Kepulauan Riau ${ }^{1}$
}

\author{
Bekti Nur Utami, Dwi Khonitan²
}

\begin{abstract}
Abstraksi
Penelitian dilakukan di Desa Bukit Langkap, Kabupaten Lingga, Kepualauan Riau. Desa Bukit Langkap merupakan desa transmigrasi yang dibentuk pada tahun 1988. Sebanyak 80\% lahan masyarakat belum dibuka dan dimanfaatkan. Pembukaan lahan yang dilakukan masyarakat berbasis social entrepreneurship. Tujuan penelitian (1) mengetahuai proses pemberdayaan masyarakat berbasis social enterpreneurship di bidang pertanian dan peternakan (2) mengetahui faktor pendukung dan penghambat dalam pemberdayaan masyarakat berbasis social enterpreneurship di bidang pertanian dan peternakan. Metode penelitian adalah kualitatif dengan teknik analisis data pendekatan deskriptif desain Grounded Theory Approach. Sampel yang digunakan adalah purposive sampling sebanyak 33 orang yang dipilih. Pengumpulan data dilakukan melalui observasi, wawancara dan dokumentasi. Validasi data dilakukan dengan cara member checking. Analisis data menggunakan open, axial, dan selective coding. Hasil penelitian menunjukkan bahwa proses pemberdayaan masyarakat melalui tahapan (1) Penyadaran, melibatkan tokoh masyarakat sebagai penyuluh, penggerak, motivator dan teladan, (2) Pengakapasitasan, melalui kegiatan pelatihan,(3) Pendayaan, melalui otoritas masyarakat. Faktor pendukung social entrepreneurship adalah (a) Modal awal, (b) Partisipasi aktif kelompok tani dan ternak dan (c) Peran tokoh masyarakat. Faktor penghambat social entrepreneurship adalah (a) Rendahnya leadership, (b) Kurang siapnya sumberdaya manusia dan (c) Kurangnya kemampuan di bidang pertanian dan peternakan.
\end{abstract}

Kata kunci: pemberdayaan masyarakat, pertanian dan peternakan, social enterpreneurship

\begin{abstract}
Research conducted in Bukit Langkap Village, Riau Islands. As much as $80 \%$ of community land hasn't been opened and utilized. Research objectives to know: (1) process of community empowerment-based social enterpreneurship in agriculture and animal husbandry (2) the factor endowments and barrier community empowerment-based social enterpreneurship. The research method is qualitative data analysis techniques with descriptive approach with Grounded Theory Approach design and use purposive sampling numerous 33 people chosen by purposive. Data collection is carried out by observation, interview and documentation. Validation and accuracy of the data is done by of a member's checking. Data analysis using open, axial, dan selective coding. The results showed through stages (1) Awareness, engage community leaders as extension officers, driving, motivator and role model, (2) Capabilities, through training activities, (3) Leverage existing, authority of the public. The supporting factors is (a) initial capital, (b) active participation of farmers and livestock groups (c) role of community leaders. Restricting factors of social entrepreneurship is (a) low level of leadership, (b) Less prepared human resources (c) lack of ability in field of agriculture and animal husbandry.
\end{abstract}

Keywords: community empowerment, agriculture and animal husbandry, social enterpreneurship

\footnotetext{
${ }^{1}$ Untuk mengutip artikel ini: Utami, Bekti Nur, Khonitan, Dwi. 2018. "Pemberdayaan Masyarakat Berbasis "Social Entrepreunership" Bidang Pertanian dan Peternakan di Desa Bukit Langkap, Kabupaten Lingga, Kepulauan Riau". Jurnal Pemikiran Sosiologi 5 (2): 126-147

${ }^{2}$ Politeknik Pembangunan Pertanian (PolBangtan) Malang, Jawa Timur. Contact:bekti.n.utami@gmail.com
} 
Jurnal Pemikiran Sosiologi Volume 5 No. 2, 2018

Pemberdayaan Masyarakat Berbasis “Social Entrepreunership” Bidang Pertanian dan Peternakan: Studi Kasus

Desa Bukit Langkap, Kabupaten Linggau, Kepulauan Riau

Bekti Nur Utami, Dwi Khonitan

\section{A. Pendahuluan}

Desa Bukit Langkap merupakan salah satu desa di Kabupaten Lingga, Provinsi Kepulauan Riau yang memiliki jumlah kependudukan sejumlah 131 KK (Anonim, 2017). Di Desa Bukit Langkap terdapat 4 kelompok tani yang aktif dalam kegiatan pertanian dan sosial. Kelompok Tani tersebut adalah Jatayu, Buntayu, Gemaripa dan Pangestu. Selain anggota kelompok tani, masyarakat yang tidak tergabung dengan kelompok tani juga aktif di dalam kegiatan sosial pertanian. Kegiatan sosial pertanian ini adalah pembukaan lahan masyarakat yang ada di hutan dan rawa untuk dijadikan lahan persawahan produktif dan meningkatkan pendapatan masyarakat nantinya serta merantas nilai kemiskinan di desa Bukit Langkap. Walaupun masyarakat memiliki tanah yang luas, namun belum bisa menambah pendapatan. Setidaknya ada $80 \%$ lahan masyarakat di Desa Bukit Langkap yang belum diolah. Setiap KK memiliki 1 hektar tanah yang belum dibuka dan diolah, sehingga diadakanlah kegiatan pertanian yang berbasis social entrepreneurship di Desa Bukit Langkap.

Dukungan dari beberapa faktor pendukungpun juga berperan didalam pemberdayaan masyarakat pada kegiatan Social Entrepeneurship di desa Bukit Langkap, menurut Mardikanto \& Soebiato (2013, h.16) pemberdayaan merupakan serangkaian kegiatan untuk memperkuat dan atau mengoptimalkan keberdayaan (dalam arti kemampuan dan atau keunggulan bersaing) kelompok lemah dalam masyarakat, termasuk individu-individu yang megalami masalah kemiskinan. Berdasarkan Undang-Undang Republik Indonesia Nomor 19 Tahun 2013 tentang Perlindungan \& Pemberdayaan Petani pada Pasal 1 Ayat 2 tertulis pengertian pemberdayaan petani yang berbunyi "pemberdayaan petani adalah segala upaya untuk meningkatkan kemampuan petani untuk melaksanakan usaha tani yang lebih baik melalui pendidikan dan pelatihan, penyuluhan dan pendampingan, pengembangan sistem dan sarana pemasaran hasil pertanian, konsolidasi dan jaminan luasan lahan pertanian, kemudahan akses ilmu pengetahuan, teknologi dan informasi, serta penguatan kelembagaan petani". Petani perlu diberikan perlindungan serta pemberdayan supaya petani memiliki kapasitas untuk terus tumbuh dan berkembang menjadi lebih sejahtera.

Wrihatnolo dan Dwidjowijoto (2007, h.2-5) membagi tiga proses pemberdayaan, pertama, tahap penyadaran, target sasaran adalah masyarakat yang kurang mampu yang harus diberikan "pencerahan" dengan memberikan penyadaran bahwa mereka memiliki hak untuk mampu dalam menghadapi masalah yang dihadapi. Mereka harus diberikan 
Jurnal Pemikiran Sosiologi Volume 5 No. 2, 2018

Pemberdayaan Masyarakat Berbasis “Social Entrepreunership” Bidang Pertanian dan Peternakan: Studi Kasus

Desa Bukit Langkap, Kabupaten Linggau, Kepulauan Riau

Bekti Nur Utami, Dwi Khonitan

motivasi bahwa mereka mempunyai kemampuan untuk keluar dari lingkaran kemiskinan. Kedua, tahap pengkapasitasan, tahap ini terdiri dari tiga jenis pengkapasitasan yaitu pengkapasitasan manusia, organisasi dan sistem nilai. Pengkapasitasan manusia dilakukan dengan memberikan pendidikan, pelatihan, dan kegiatan lainnya untuk meningkatkan keterampilan individu atau kelompok. Pengkapasitasan organisasi dilakukan dengan melakukan restrukturisasi organisasi sehingga dapat memunculkan inovasi baru dalam perubahan yang dilakukan. Pengkapasitasan sistem nilai dilakukan dengan membuat "aturan main" didalam organisasi yang berupa peraturan yang harus dipatuhi oleh seluruh anggotanya. Ketiga, tahap pendayaan pada tahap ini target sasaran diberikan daya atau kekuatan, kekuasaan, otoritas atau peluang yang disesuaikan dengan kemampuan yang dimiliki sehingga target sasaran dapat menjalankan kekuasaan yang diberikan dan mampu membawa perubahan lebih baik.

Kegiatan social entrepreneurship telah terjadi sejak satu tahun yang lalu dengan awal pembukaan lahan sebanyak 5 orang dengan luas 1 hektare setiap orangnya dengan pembiayaan bantuan dari Kepala Desa Bukit Langkap, orientasi profit dari kegiatan ini adalah untuk memperluas lahan-lahan 
Jurnal Pemikiran Sosiologi Volume 5 No. 2, 2018

Pemberdayaan Masyarakat Berbasis “Social Entrepreunership” Bidang Pertanian dan Peternakan: Studi Kasus

Desa Bukit Langkap, Kabupaten Linggau, Kepulauan Riau

Bekti Nur Utami, Dwi Khonitan

\section{B. Metode Penelitian}

Penelitian ini bertujuan untuk

(1) Mengetahui bagaimana pemberdayaan masyarakat yang berbasis social enterpreneurship di bidang pertanian dan peternakan

(2) Mengetahui faktor pendukung dan penghambat dalam pemberdayaan masyarakat berbasis social enterpreneurship dibidang pertanian dan peternakan.

Penelitian dilakukan di Desa Bukit Langkap Kabupaten Lingga Provinsi Kepulauan Riau. Metode penelitian menggunakan pendekatan kualitatif desain Grounded Theory Approach. Objek dalam penelitian ini adalah proses pemberdayaan masyarakat yang berbasis social enterpreneurship serta faktor pendukung dan penghambat pemberdayaan masyarakat berbasis social enterpreneurship bidang pertanian dan peternakan di desa Bukit Langkap Kabupaten Lingga.

Teknik analisis data dengan pendekatan deskriptif dimana selama berada di lapangan mencakup tiga kegiatan secara bersamaan:

(1) reduksi data,

(2) penyajian data,

(3) penarikan kesimpulan (verifikasi).

Sampel yang digunakan adalah purposive sampling yaitu dengan memilih orang yang paling membantu dalam memahami fenomena sentral (Creswell, 1998). Informan yang menjadi sumber data dalam penelitian ini sebanyak 33 orang yang terdiri dari Kepala Desa, Sekretaris Desa, Ketua PKK, Ketua RW, Ketua RT, 4 orang pemuda anggota karang taruna dan masyarakat umum yang sebanyak 13 ibu rumah tangga dan 11 kepala keluarga. Pengumpulan data dilakukan dengan cara observasi, wawancara dan dokumentasi. Analisis data menggunakan open, axial, dan selective coding (Strauss\&Corbin,1998) untuk menganalisis data.

Observasi yang dilaksanakan adalah observasi partisipatif jenis partisipatif pasif. Observasi dilakukan terhadap kegiatan penanaman sampai pemanenan padi di Desa Bukit Langkap selama 3 bulan. Alat yang digunakan dalam obervasi ini adalah catatan-catatan untuk merekam setiap peristiwa yang terjadi selama observasi. Teknik wawancara dalam penelitian ini berjenis wawancara semiterstruktur. Alat yang digunakan untuk merekam hasil wawancara berupa handphone berjenis smartphone dalam bentuk file berekstensi.amr. instrumen penelitian merujuk pada penelitian terdahulu dari Certo \& Miller (2008). Dokumentasi yang dilakukan berupa pengumpulan foto selama kegiatan berlangsung yang dikumpulkan dalam satu bentuk folder. Validasi dan keakuratan data dilakukan dengan cara member checking. 
Jurnal Pemikiran Sosiologi Volume 5 No. 2, 2018

Pemberdayaan Masyarakat Berbasis “Social Entrepreunership” Bidang Pertanian dan Peternakan: Studi Kasus

Desa Bukit Langkap, Kabupaten Linggau, Kepulauan Riau

Bekti Nur Utami, Dwi Khonitan

\section{Temuan Penelitian dan Pembahasan Hasil Penelitian: Praktik "Social Entrepreunership"}

Desa Bukit Langkap merupakan desa transmigrasi yang dibentuk pada tahun 1988. Letak Desa Bukit Langkap berada di antara dua bukit yaitu bukit bayi dan bukit syaigon di Pulau Lingga Provinsi Kepualauan Riau. Penduduk Desa Bukit Langkap adalah Warga Negara Indonesia yang mengikuti program transmigrasi. Mayoritas penduduk berasal dari sejumlah daerah di Jawa seperti Pati, Tegal, dan Klaten. Jumlah penduduk sebanyak 131 Kepala Keluarga. Setiap kepala keluarga mendapat lahan seluas 2,5 hektar. Sebagian lahan tersebut digunakan pendirian rumah, namun masih banyak lahan yang belum dibuka dan dimanfaatkan. Setiap kepala keluarga memiliki lahan yang belum dimanfaatkan berukuran sekitar 1,5 hektar.

Oleh karena itu, jika di Desa Bukit Langkap ada 131 KK maka terdapat sekitar 196,5 hektar lahan yang belum dibuka dan dimanfaatkan. Lahan yang belum dibuka tersebut masih dalam keadaan hutan belantara dan rawa, namun sudah memiliki sertifikat. Berdasarkan hasil analisis PUTK (Perangkat Uji Tanah Kering), tanah di Desa Bukit Langkap mempunyai $\mathrm{pH}$ sebesar 5-6 yang tergolong sedikit masam. Tanah tersebut cocok untuk penanaman padi dan hijauan pakan ternak dengan perlakuan pengolahan lahan dengan pemupukan.

Kebutuhan pokok pangan masayarakat Desa Bukit Langkap diperoleh dari ibukota kecamatan. Jarak desa Bukit Langkap ke ibukota kecamatan sejauh $25 \mathrm{~km}$. Pasokan bahan pangan di ibukota kecamatan berasal dari Batam atau pulau-pulau sekitar yang diangkut dengan kapal. Cuaca sangat berpengaruh bagi pelayaran kapal dalam pengangkutan bahan pangan tersebut, sehingga sering mengalami keterlambatan apabila cuaca sedang buruk. Selain itu, dengan terus meningkatnya pertumbuhan penduduk di Desa Bukit Langkap, menyebabkan bertambahnya kebutuhan pangan. Hal tersebut, mendorong Bupati Lingga, H. Alias Wello, S.IP, merancang program pembangunan pertanian dan peternakan pada masa jabatannya. Salah satu program kegiatan pembangunan pertanian adalah pembukaan lahan hutan untuk dijadikan sawah. Pencetakan sawah tersebut bertujuan untuk memproduksi padi karena kebutuhan pangan beras masih dipasok dari daerah lain. Hal ini dikarenakan subsektor tanaman bahan makanan di Kabupaten Lingga masih mencakup tanaman ubi kayu dan ubi jalar (Kabupaten Lingga, 2013). Pembangunan di bidang peternakan yaitu pemanfaatan lahan untuk pembuatan kandang koloni sebagai tempat budidaya ternak. Selain itu, 
Jurnal Pemikiran Sosiologi Volume 5 No. 2, 2018

Pemberdayaan Masyarakat Berbasis “Social Entrepreunership” Bidang Pertanian dan Peternakan: Studi Kasus

Desa Bukit Langkap, Kabupaten Linggau, Kepulauan Riau

Bekti Nur Utami, Dwi Khonitan

pembukaan lahan juga dimnfaatkan untuk penanaman hijauan pakan ternak.

Kegiatan program pembangunan pertanian dan peternakan yang dilakukan masyarakat di Desa Bukit Langkap berbasis social entrepreneurship. Elemen utama dalam Social entrepreneurship adalah :

\section{Social value (Nilai Sosial)}

Social value merupakan eleman khas dari social entreprenerurship yaitu menciptakan manfaat sosial yang nyata bagi masyarakat dan lingkungan sekitarnya. Manfaat sosial yang bisa dirasakan bagi masyarakat Desa Bukit Langkap adalah

\section{a. Jalan menuju sawah yang lebih baik}

Jalan menuju sawah semula jelek, yaitu berupa jalan tanah biasa. Jalan tanah tersebut, apabila hujan menjadi berlumpur dengan air yang menggenang sehingga menyulitkan petani melewatinya bahkan tidak bisa dilewati. Pada pengembangan fasilitas publik ini sangat berpengaruh dalam kehidupan masyarakat, Warok mengatakan "Dengan adanya perbaikan jalan ini sangat mendukung saya untuk membantu orangtua dalam pengambilan hasil panen, tidak perlu lagi pengangkutan dengan jalan kaki, lebih efisien karena motor saya bisa masuk". Adanya laba hasil penjualan padi melalui BUMDes digunakan sebagai dana untuk memperbaiki jalan menuju sawah. Jalan menuju sawah ditimbun dengan batu dan kerikil sehingga jalan keras dan apabila hujan tidak berumpur. Jalan menuju sawah yang lebih baik menjadikan petani tetap beremangat ke sawah meskipun turun hujan. Sudarmin selaku kepala desa mengatakan "memberikan dorongan positif dengan memperbaiki akses jalan melalui laba bersama, menurut saya bisa meningkatkan motivasi lebih dari para petani".

\section{b. Pembukaan lahan untuk penanaman} hijauan pakan ternak

Lahan milik masyarakat yang masih berupa hutan belantara mulai dibuka. Pembukaan lahan menggunkan alat dan mesin pertanian. Pembukaan hutan bertujuan untuk menyedikan lahan penanaman hijauan pakan ternak. Dana pembukaan lahan hutan diperoleh dari laba hasil penjualan pupuk organik yang dipasarkan melalui BUMDes. Atik menyatakan bahwa sangat kreatifnya bapak-bapak dan karang taruna di desa tersebut dalam mengubah kotoran sapi menjadi uang untuk menhasilkan keuntungan bersama membuat desa tersebut menjadi desa yang aktif serta kreatif dalam kegiatan kebersamaan.

\section{Civil society}

Social society pada social entrepreneurship pada umumnya merupakan pengoptimalan 
Jurnal Pemikiran Sosiologi Volume 5 No. 2, 2018

Pemberdayaan Masyarakat Berbasis “Social Entrepreunership” Bidang Pertanian dan Peternakan: Studi Kasus

Desa Bukit Langkap, Kabupaten Linggau, Kepulauan Riau

Bekti Nur Utami, Dwi Khonitan

modal sosial yang berasal dari inisiatif dan partisipasi masyarakat, di Desa Bukit Langkap sendiri Social society sudah terlihat sangat jelas ketika kami berbaur dalam kegiatan masyarakat sehari-hari.

\section{a. Norma}

Social society di masyarakat Desa Bukit Langkap ditunjukkan dengan adanya pembentukan organisasi baru. Organisasi tersebut merupakan organisasi yang mengelola social entrepreneurship di Desa Bukit Langkap. Pada organisasi tersebut disusun struktur organisasi yang mempunyai fungsi dan tugas untuk tiap-tiap bidangnya. Beberapa bidang yang diemban dalam pembagian tugas ini antara lain bidang pengadaan yang mengatur pembiayaan dan pembagian keuntungan antar anggota, bidang penyediaan sarana prasarana bertugas untuk menyediakan kebutuhan pelaksanaan kegiatan, bidang teknisi bertugas untuk pelaksanaan kegiatan dengan arahan dari pihak BPTP, serta bidang administrasi dengan tugas pencatat segala kegiatan dan data yang diperlukan kelompok. Aturan juga dibuat untuk menjalankan aktifitas organisasinya. Aturan dalam kepengurusan program ini pada hakekatnya dibentuk dari, oleh dan untuk anggota kelompok pengurus program dipilih dari anggota kelompok yang mau dan mampu mendukung pengembangan program, memiliki kualitas seperti kesediaan mengabdi, rasa keterpanggilan, mampu mengorganisasikan dan mengkoordinasikan kegiatan anggotanya, mempunyai keuletan, pengetahuan dan pengalaman yang cukup serta yang penting adalah merupakan hasil pilihan dari anggotanya.

\section{b. Kepercayaan}

Kepala Desa Bukit langkap, Bapak Sudarmin mempunyai insiatif dana awal yang diperlukan untuk social entrepreneurship. Dana awal untuk pembukaan lahan seluas 10 hektar sebanyak Rp 50 juta berasal dari APBDes. Dana yang diberikan akan dikembalikan secara berangsur melalui keuntungan dari kegiatan social entrepreneuship, secara berkala dana akan terus berputar untuk mengembangkan program selanjutnya, meningat dana tersebut adala dana yang diberikan untuk kesejahteraan ekonomi dan sosial masyarakat. Masyarakat juga percaya, bahwa social entrepreneurship berbasis pertanian dan peternakan yang dilakukan akan berhasil, sehingga masyarakat melaksanakannya dengan sungguh-sungguh dan sesuai aturan serta rencana yang tela disusun sebelumnya.

\section{c. Gotong-royong}

Masyarakat Desa bukit Langkap secara bergotong-royong berpartisipasi dalam pelaksanaan pembukaan lahan hutan. Pembukaan lahan hutan dilaksanakan secara 
Jurnal Pemikiran Sosiologi Volume 5 No. 2, 2018

Pemberdayaan Masyarakat Berbasis “Social Entrepreunership” Bidang Pertanian dan Peternakan: Studi Kasus

Desa Bukit Langkap, Kabupaten Linggau, Kepulauan Riau

Bekti Nur Utami, Dwi Khonitan

bertahap. Konsep gotong royong juga dapat dimaknai dalam konteks pemberdayaan masyarakat (Pranadji, 2009: 62), karena bisa menjadi modal sosial untuk membentuk kekuatan kelembagaan di tingkat komunitas, masyarakat negara serta masyarakat lintas bangsa dan negara Indonesia dalam mewujudkan kesejahteraan. Hal tersebut juga dikarenakan di dalam gotong royong terkandung makna collective action to struggle, self governing, common goal, dan sovereignty

Tahap pertama dalam kegiatan Social Entreprenurship dibuka seluas 10 hektar. Proses pembukaan lahan dilakukan menggunakan alat dan mesin pertanian. Tujuan pembukaan lahan tersebut adalah untuk pencetakan sawah. Secara bergotongroyong, masyarakat desa juga berpartisipasi dalam mencetak sawah baru. Bapak-bapak berpartisipasi menyumbangkan tenaga dan ibu-ibu menyediakan makanan dan minuman.

\section{d. Jaringan}

Pengetahuan dan keterampilan masyarakat Desa Bukit Langkap mengenai teknis pertanian dan peternakan masih rendah. Peningkatan pengetahuan dan keterampilan teknis pertanian dan peternakan bagi masyarakat dilakukan dengan mengadakan pelatihan. Ketua kelonpok tani Slamet mengatakan "Banyaknya pelatihan yang diberikan membuat kami memiliki banyak pengetahuan dan keterampilan khususnya bisa meningkatkan penghasilan". Pelatihan tersebut melibatkan pihak luar sebagai narasumber dan pelatih. Pihak luar yang terlibat adalah Bank Indonesia dan Balai Penelitian Teknologi Pertanian Provinsi Kepulauan Riau, dengan adanya keterkaitan beberapa pihak luar desa kegiatan sosial berupa socio entrepreneurship dapat berjalan dengan baik karena memiliki dukungan penuh dari pihak yang berkompeten.

\section{Innovation}

Inovasi yang diterapkan oleh masyarakat Desa Bukit Langkap merupakan penerapan teknologi baru di bidang pertanian dan peternakan yang memadukan kearifan lokal. Inovasi tersebut adalah

\section{a. Pembuatan pupuk organik}

Masayarakat Desa Bukit Langkap mempunyai kegemaran memelihara sapi potong jenis bali. Setiap kepala keluarga memiliki minimal satu ekor sapi. Sapi tersebut dipelihara bebas di halaman rumah. Kotoran sapi semula belum dimanfaatkan, hanya dibiarkan bigitu saja. Kemudian ada pelatihan pembuatan pupuk organik bagi masyarakat Bukit Langkap yang diselenggarakan oleh Bank Indonesia. 


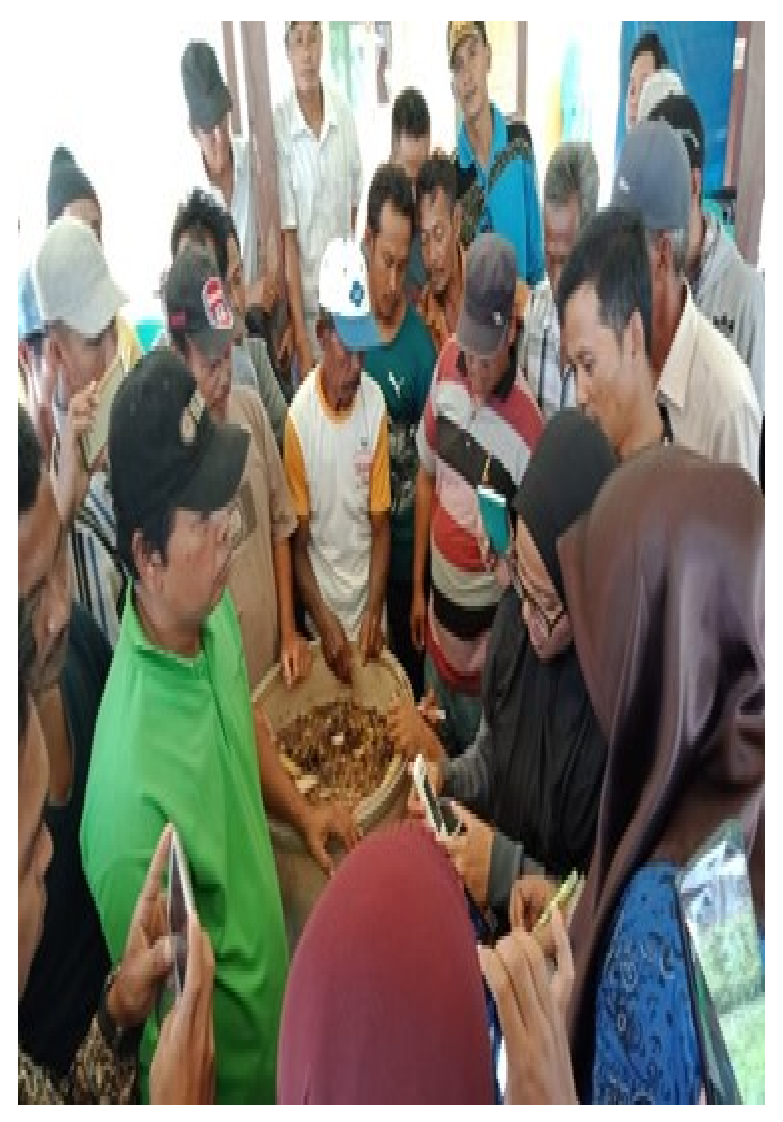

Gambar 01. Kegiatan pelatihan pembuatan pupuk organik (Sumber: Dokumentasi Data Primer/ Observasi)

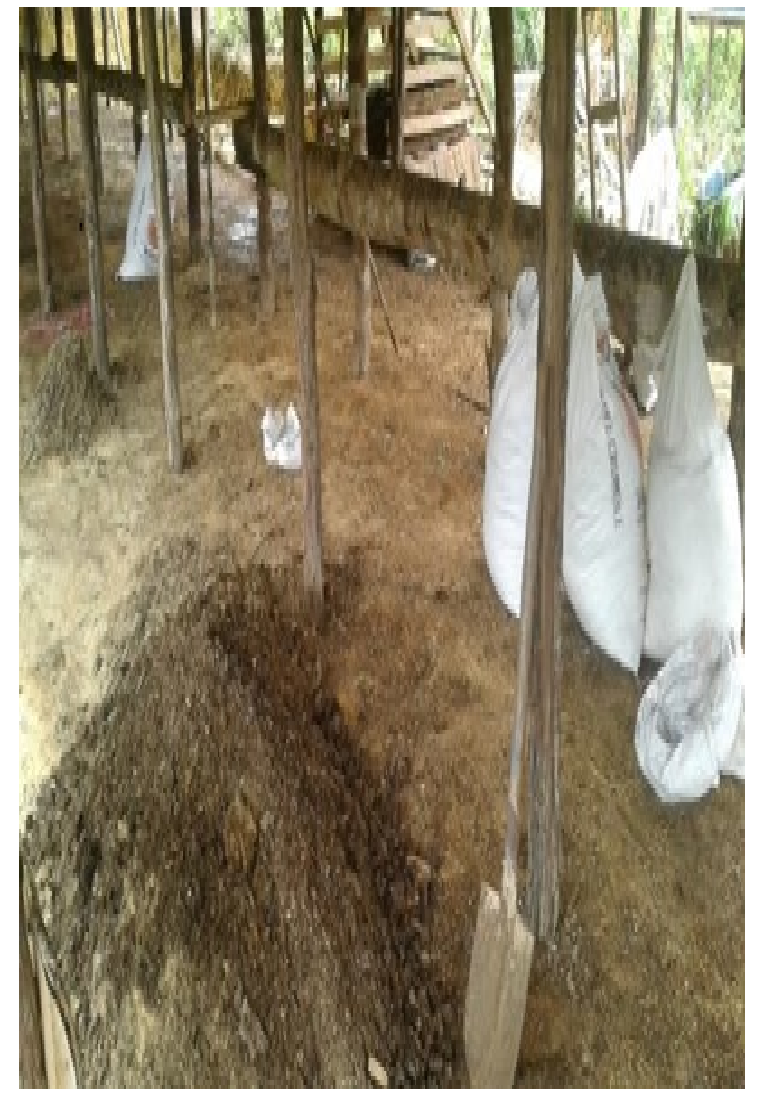

Gambar 02. Hasil pupuk organik dari limbah kotoran ternak (Sumber: Dokumentasi Data Primer/Observasi)

Setelah masyarakat bisa mengolah kotoran sapi menjadi pupuk organik, selanjutnya kotoran tersebut dikumpulkan dan dibuat menjadi pupuk organik dengan sentuhan teknologi fermentasi. Pupuk organik hasil pengolahan tersebut digunakan untuk pemupukan tanaman dan selebihnya dijual dengan dipasarkan melaui BUMDes. 
Jurnal Pemikiran Sosiologi Volume 5 No. 2, 2018

Pemberdayaan Masyarakat Berbasis “Social Entrepreunership” Bidang Pertanian dan Peternakan: Studi Kasus

Desa Bukit Langkap, Kabupaten Linggau, Kepulauan Riau

Bekti Nur Utami, Dwi Khonitan

b. Penanaman padi sawah dengan metode tanpa olah tanah

Tanah di Desa Bukit Langkap merupakan tanah yang masam. Produksi padi yang dihasilkan masyarakat Desa Bukit Langkap masih rendah. Hal tersebut karena masyarakat belum mempunyai pengetahuan dan keterampilan budidaya pada jenis tanah masam. Kemudian diadakan pelatihan menganai budidaya padi tanpa olah tanah oleh Balai Bengkajian Penerapan Teknologi (BPTP) Badan Penelitian dan Pengembangan Pertanian di Kepulauan Riau.

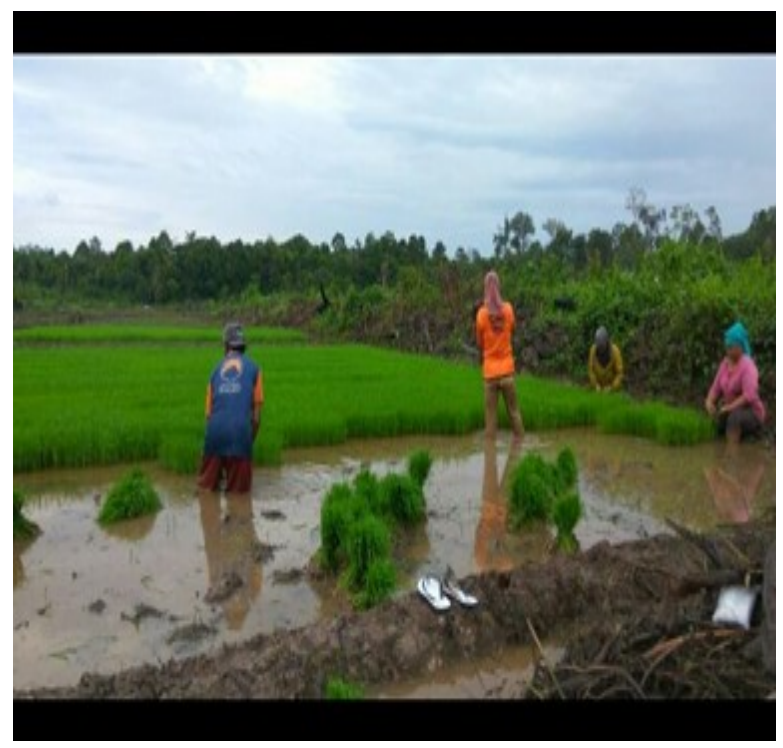

Gambar 3. Kegiatan pemindahan bibit padi Inpari 30 untuk dipindahkan ke lahan sawah (Sumber: Dokumentasi Data Primer/ Observasi).

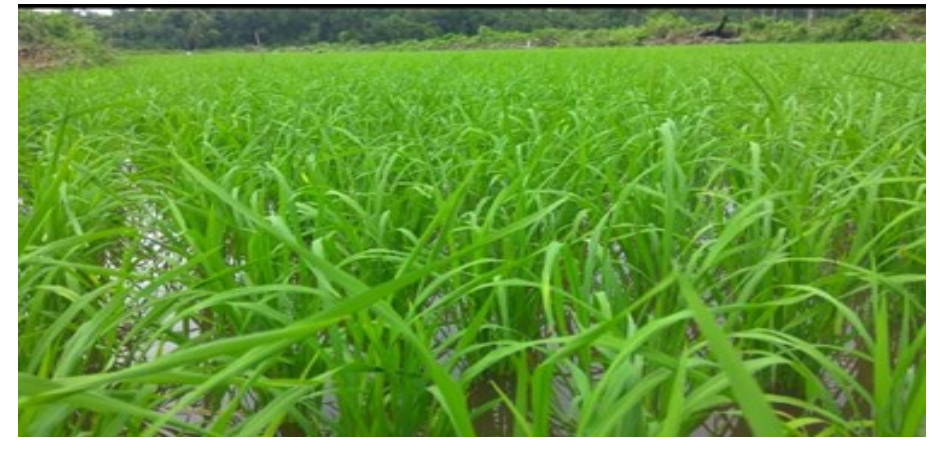

Gambar 4. Pertumbuhan Padi Inpari 30 yang sudah dipindahkan ke lahan sawah (Sumber: Dokumentasi Data Primer/Observasi).

Penanaman padi tidak perlu dilakukan olah tanah. Hanya saja tanah perlu diberi kapur dan pemupukan di bagian permukaan tanah tanpa proses pembalikan tanah. Setelah pemupukan kemudian langsung dilakukan penanaman. Wati seorang petani mengatakan "Baru kali ini inovasi yang belum perah diberian pada kami bisa membantu kegiatan bertanam padi, waktu singkat dan kelihatanya hasilnya juga akan maksimal daripada panen sebelumnya". Setelah Produksi padi yang dihasilkan lebih banyak dengan cara penanaman padi tanpa olah tanah dari pada melalui proses olah tanah

\section{c. Penanaman hijauan pakan ternak}

Penanaman hijauan pakan ternak merupakan salah satu kegiatan dalam pembangunan peternakan di Desa Bukit Langkap. Lokasi penamanan hijauan pakan ternak dilakukan di lahan hutan yang dibuka. Lahan hijauan pakan ternak dapat dimanfaatkan oleh masyarakat desa sebagai lahan penyedia pakan dan lahan 
Jurnal Pemikiran Sosiologi Volume 5 No. 2, 2018

Pemberdayaan Masyarakat Berbasis “Social Entrepreunership” Bidang Pertanian dan Peternakan: Studi Kasus

Desa Bukit Langkap, Kabupaten Linggau, Kepulauan Riau

Bekti Nur Utami, Dwi Khonitan

penyedia bibit pakan yang dapat diperbanyak. Awal penanaman, bibit tanaman hijauan pakan ternak adalah melalui bantuan bibit dari pihak Balai Penelitian Teknologi Pertanian Provinsi Kepualauan Riau dengan jumlah tanam sekitar 2.000 lubang tanam per satu hektar dengan bibit berupa stek rumput gajah odot, Rumput gajah jenis ini berbeda dari rumput gajah yang biasa dibudidayakan oleh petani saat ini.

Rumput gajah biasa tingginya sekitar 4,5 meter, sedangkan rumput odot bisa mencapai satu meter, dengan rumpun yang sangat rapat mirip pandan. Dengan kondisi ini, tentunya rumput odot jauh lebih efisien dalam penggunaan lahan. Untuk lahan 1 meter persegi rumput gajah biasa hanya menghasilkan sekitar 29,5 kg/ha/tahun, maka rumput odot bisa mencapai sekitar 36 $\mathrm{kg} /$ tahun. Hampir semua bagian rumput odot bisa dimakan oleh sapi, sedangkan rumput gajah biasa hanya sekitar 60-70 \% saja. (Bramanda dan Handian, 2014). Penananaman dilakukan dengan cara membuat lubang dengan ukuran $30 \mathrm{~cm}$ x 30 $\mathrm{cm}$ dengan jarak sistem tanam yaitu jajar legowo 2:1, dengan jarak tanam antar keduanya yaitu $60 \mathrm{~cm}$, pengolahan tanam dengan mesin berupa jhondeer dengan 2 alat bantu yaitu singkal dan rotari. Pengolahan lahan ini berfungsi untuk mengolah tanah agar pupuk yang dicampurkan dapat meresap dengan sempurna. Selain itu pemberian kapur juga dilakukan untuk menurunkan kadar keasaman pada tanah yang diolah sehingga kadar keasaman tanah netral atau berada pada angka 7. Dengan lubang sejumlah 2.000 per hektar nantinya mampu memenuhi kebutuhan hijauan pakan ternak tepatnya sapi bali di Desa Bukit Langkap. Penanaman hijauan pakan ternak ini juga diperhatikan Carry Capacity dari lahan sehingga kebutuhan ternak sebanyak jumlah sapi di desa dapat dicukupi dengan baik.

\section{d. Pembuatan kandang koloni}

Pembukaan lahan hutan juga dimanfaatkan untuk pembangunan di bidang peternakan. Inovasi di bidang peternakan yaitu pembuatan kandang koloni. Kandang koloni tersebut bertujuan untuk menampung semua ternak sapi yang ada di Desa Bukit Langkap. Masyarakat masih membuat kandang di dekat rumah atau bahkan ada yang menempel dengan rumah. Kandang yang dekat dengan rumah akan mengganggu kesehatan dari ternak maupun pemiliknya. Penggembalaan sapi dengan cara membiarkan berkeliaran di halaman sekitar rumah. Hal tersebut menyebabkan kotoran yang tercecer dimanamana di halaman rumah. Kotoran tersebut mengganggu kesehatan dan keindahan. Oleh karena itu, pembuatan kandang koloni letaknya terpisah dari lokasi perumahan masyarakat Desa Bukit Langkap. Pemilihan 
Jurnal Pemikiran Sosiologi Volume 5 No. 2, 2018

Pemberdayaan Masyarakat Berbasis “Social Entrepreunership” Bidang Pertanian dan Peternakan: Studi Kasus

Desa Bukit Langkap, Kabupaten Linggau, Kepulauan Riau

Bekti Nur Utami, Dwi Khonitan

lokasi pembuatan kandang koloni yang jauh dari perumahan adalah selain karena alasan kesehatan dan kemudahan dalam pemeliharaan.

Syarat kandang yang baik juga sangat diperhatikan berdasarkan penggunaanya kandang sapi dapat berupa kandang barak ataupun kandang individual. Luas kandang barak diperhitungkan ridak boleh kurang dari 2,0 m2/ekor agar ternak lebih leluasa bergerak, sedangkan kandang individual dapat lebih kecil daripada kandang barak yaitu sekitar1m7 km m2 /ekor dengan masing-masing sapi sebesar $150 \mathrm{~kg}$. Palungan pakan sapi bisa dalam bentuk memanjang dan terbuka, palungan ini biasanya terbuat dari kayu dengan panjang sekitar $3 \mathrm{~m}$ dan lebar 0,75 m yang mamu menyediakan pakan untuk 10-14 ekor sapi, selain dalam bentuk permanen palungan pakan ini dapat pula dibuat dalam bentuk yang dapat dipindahkan tempatkan atau didorong atau dihela (Santosa, 2011) Lantai kandang koloni menggunakan lantai semen atau betton berpori (model wavin) terutama pada bagian lantai yang tidak beratap. Pada bagian belakang kandang dilengkapi selokan pembuangan terutama untuk menjaga kebersihan lantai kandang pada musim hujan. Alas lantai pada model kandang ini tidak menggunakan alas dasar litter, namun bahan alas litter hanya disebarkan pada lantai (terutama lantai yang beratap) yang becek. Pembuangan feses dilakukan secara berkala yaitu tiga sampai empat kali setahun atau sesuai kebutuhan.

Kelebihan sistem perkandang koloni semiintensif adalah ternak lebih bebas dan adanya rak penyimpanan pakan kering (seperti jerami) sehingga pakan hijauan kering selalu tersedia. perlu mendapat perhatian untuk kandang pembesaran adalah kepadatan kaitannya dengan kecukupan sarana (palungan), dan kondisi ternak yang dipelihara dalam satu kandang harus mempunyai kondisi badan yang sama atau hampir sama, untuk menghindari persaingan sesamanya. Pemeliharaan berikutnya setelah dari kandang pembesaran dilakukan pemisahan antara jantan dan betina, yaitu ternak jantan dipelihara pada kandang penggemukan atau sebagai calon pejantan dan yang betina sebagai replacement stok untuk calon induk.

Kandang penggemukan untuk pemeliharaan sapi jantan dewasa beberapa bulan sampai mencapai bobot tertentu. Lama pemeliharaan ternak pada kandang penggemukan berkisar antara 4 - 12 bulan, tergantung pada kondisi awal ternak (umur dan bobot badan) dan ransum yang diberikan. Tipe kandang untuk penggemukan jantan dewasa adalah tipe kandang individu dalam kandang koloni, untuk menghindari perkelahian sesamanya. (Hartati dan Ainun, 2007). Pembuatan 
Jurnal Pemikiran Sosiologi Volume 5 No. 2, 2018

Pemberdayaan Masyarakat Berbasis “Social Entrepreunership” Bidang Pertanian dan Peternakan: Studi Kasus

Desa Bukit Langkap, Kabupaten Linggau, Kepulauan Riau

Bekti Nur Utami, Dwi Khonitan

kandang koloni dibantu oleh Bank Indonesia

Provinsi Kepulauan Riau dalam pendanaanya beserta kelompok ternak Jatayu dalam ketenagaan dan beberapa perangkat desa terkait yang bertugas dalam kegiatan socialenterperenuship.

\section{Economic activity (Aktivitas Ekonomi)}

Social entrepreneurship di desa Bukit Langkap berhasil menyeimbangkan antara aktivitas sosial dan aktivitas bisnis. Aktifitas bisnis/ekonomi dikembangkan untuk menjamin kemandirian dan keberlanjutan aktifitas sosial.

\section{a. Kawasan Rumah Pekarangan Lestari} (KRPL)

Pengembangan KRPL di Desa Bukit Langkap dilakukan oleh ibu-ibu anggota kelompok wanita tani Bukit Langkap Kegiatan KRPL mempunyai misi sosial yaitu menciptakan kawasan yang rindang, bersih dan indah secara gorong-royong. Selain itu, kegiatan KRPL juga bertujuan pada output ekonomi yaitu untuk memperoleh keuntungan dari hasil penjualan sayuran segar. Keuntungan lain yang didapat yaitu dari pengolahan sayuran menjadi stik seperti stik kangkung, bayam dan sebagainya. Kegiatan KRPL dapat menambah pendapatan masyarakat. Dari hasil KRPL, setiap rumah bisa mengumpulkan $5 \%$ labanya untuk dikumpulkan ke dalam kas kelompok wanita tani Bukit Langkap
Selanjutnya kas KWT digunakan untuk penghijauan fasilitas umum seperti menaman sayuran di balai desa.

\section{b. Pupukorganik}

Hasil pengolahan pupuk organik dipasarkan melalui BUMDes. Laba penjualan pupuk organik dikumpulkan untuk social enterepreneurship. Aktifitas sosial dari hasil aktifitas bisnis yang dilakukan masyarakat desa di bidang peternakan yaitu pembukaan lahan untuk penanaman tanaman hijauan pakan ternak dan pembangunan kandang koloni sapi bali masyarakat Desa Bukit Langkap. "Selain rumputnya bisa dimanfaatkan menjadi pakan ternak kami, tanah yang baru dibuka ini juga semakin berjalannya waktu semakin tekstur tanahnya membaik dengan pupuk organik" tutur Erna pemilik lahan.

c. Padi

Lahan hutan yang dibuka sebagian digunakan untuk pencetakan sawah. Pada sawah yang dicetak tersebut ditanami padi jenis Inpari 30. Beras hasil panen dipasarkan di BUMDes. "Beras yang kami pasarkan di BUMDes diberikan label nama Jagung Manis, melalui brand ini diharapkan mampu terjual dipasaran dengan baik" ucap Sudarmin. Laba penjualan pemasran padi digunakan untuk 
Jurnal Pemikiran Sosiologi Volume 5 No. 2, 2018

Pemberdayaan Masyarakat Berbasis “Social Entrepreunership” Bidang Pertanian dan Peternakan: Studi Kasus

Desa Bukit Langkap, Kabupaten Linggau, Kepulauan Riau

Bekti Nur Utami, Dwi Khonitan

social entrepreneurship yaitu untuk perbaikan jalan atau infrastruktur menuju sawah. Pembangunan tempat giling bersama saat ini juga menjadi slaah satu hasil dari keberhasilan social enterpreneurship di Desa Bukit Langkap. Setelah bertahun-tahun harus menggiling hasil panen menuju desa sebelah dengan jarak sekitar $12 \mathrm{~km}$ dan harus melalui jalan dengan keadaan sulit. Pendirian tempat mesin giling ini sangat diapresiasi oleh masyarakat karena sangat membantu dalam meningkatkan efektivitas kegiatan social entrepreneurship, pembiayaan dalam pendirian tempat penggilingan ini berasal dari APBDes dengan inisiatif Kepala Desa Bukit Langkap, sehingga dana dapat tersalurkan dalam rangka memenuhi kebutuhan pascapanen padi dari kegiatan social entrepreneurship.

\section{Proses Pemberdayaan Masyarakat di Desa Bukit Langkap}

Pemberdayaan masyarakat yang berbasis social enterpreneurship di Desa Bukit dilakukan melalui kegiatan pertanian. Pemberdayaan masyarakat di Desa Bukit Langkap dilakukan secara swadaya untuk meningkatkan kesejahteraan ekonomi masyarakat. Adapun proses pemberdayaan tersebut antara lain:

\section{Penyadaran}

Sebanyak 80\% masyarakat di Desa Bukit Langkap (Anonim, 2018) memiliki lahan yang belum dibuka dan diolah untuk diproduksi sebagai lahan produktif. Sebanyak 40\% dari $80 \%$ masyarakat adalah penduduk yang tergolong dalam status pendapatan menengah ke bawah. Tujuan pemberdayaan masyarakat adalah untuk merubah status sosial sehingga masyarakat akan memperoleh kesejahteraan hidupnya, salah satunya yaitu melalui social entrepeneurship. Social entrepreneurship ditunjukkan dengan kegiatan pembukaan lahan pertanian.

Social entrereneurship dapat berjalan dengan baik karena keterlibatan tokoh masyarakat. Tokoh masyarakat di Desa Bukit Langkap yaitu kepala desa, ketua RT, ketua RW, ketua PKK, Tokoh agama dan ketua karang taruna. Peran tokoh masyarakat adalah sebagai :

\section{a. Penyuluh}

Tokoh masyarakat yang berperang sebagai penyuluh dalam social entrepreneurship adalah Kepala Desa Bukit Langkap, Bapak Sudarmin. Kepala desa bersama Petugas Penyuluh Lapangan (PPL) Desa Bukit Langkap, Bapak Marwanto, melakukan penyuluhan pemasaran Beras Cap Jagung Manis. Beras Cap jagung Manis adalah beras hasil produksi anggota kelompok tani Jatayu Desa Bukit langkap. Kepala Desa Bukit 
Jurnal Pemikiran Sosiologi Volume 5 No. 2, 2018

Pemberdayaan Masyarakat Berbasis “Social Entrepreunership" Bidang Pertanian dan Peternakan: Studi Kasus

Desa Bukit Langkap, Kabupaten Linggau, Kepulauan Riau

Bekti Nur Utami, Dwi Khonitan

Langkap mewajibkan masyarakat

memasarkan beras hasil panenan kelompok

tani nya di BUMDes. Beras produksi petani di wilayah Desa Bukit Langkap yang dipasarkan melalui BUMDes bertujuan untuk memenuhi kebutuhan konsumsi masyarakat di wilayah Desa Bukit Langkap selain itu juga dipasarkan di kabupaten kota bahkan bupati sudah mengapresiasi tentang pemasaran beras Cap Jagung Manis ini, nantinya setiap pegawai yang ada di Kabupaten Lingga akan diwajibkan untuk makan nasi dari hasil petani Kabupaten Lingga terkhusus dari Desa Bukit Langkap. Selain itu, laba keuntungan penjualan akan digunakan untuk social entrepreneurship yaitu memperluas lahan pertanian di Desa Bukit Langkap.

Di bidang peternakan, kepala desa juga berperan sebagai penyuluh peternakan. Penyuluhan di bidang peternakan yaitu pembuatan kandang koloni untuk kelompok ternak. Ternak milik masyarakat desa akan dikumpulkan di kandang koloni sehingga memudahkan dalam pemeliharaan. Selain itu, kotoran ternak akan mudah dikumpulkan untuk selanjutnya dibuat pupuk organik. Pupuk organik hasil olahan akan digunakan untuk pemupukan tanaman dan selebihnya dipasarkan melalui BUMDes. Laba hasil penjulan pupuk organik digunakan untuk social entrepreneurship. Social entrepreneurship di bidang peternakan yaitu penanaman hijauan pakan ternak dan perluasan kandang koloni.

\section{b. Penggerak}

Tokoh masyarakat yang berperan sebagai penggerak dalam social entrepreneurship adalah

\section{(1) Ketua PKK}

Ketua PKK yang berperan sebagai penggerak yaitu Ibu Atik. Ketua PKK merupakan sosok yang mempunyai jiwa kepemimpinan yang tinggi sehingga dapat menggerakkan anggotanya untuk melaksakana kegiatan KRPL.

\section{(2) Ketua Karang Taruna}

Ketua karang taruna yaitu Mas Pujo berperan sebagai penggerak di kalangan pemuda. Para pemuda karang taruna bersama ibu-ibu PKK membuat demplot pertanian. Jadwal demplot pertanian diatur yaitu para peuda yang masih bersekolah bertugas di hari minggu ketika libur, sedangkan hari selain itu adalah tugas ibu-ibu PKK sehingga kegiatan demplot berjalan dengan lancar.

\section{(3) Ketua RT dan Ketua RW}

Pak Sono sebagai ketua RT dan Pak Marno sebagai ketua RW juga merupakan tokoh masyarakat yang berperan dalam social enterpreneurship di Desa Bukit Langkap. Ketua RT dan Ketua RW berperan 
Jurnal Pemikiran Sosiologi Volume 5 No. 2, 2018

Pemberdayaan Masyarakat Berbasis “Social Entrepreunership” Bidang Pertanian dan Peternakan: Studi Kasus

Desa Bukit Langkap, Kabupaten Linggau, Kepulauan Riau

Bekti Nur Utami, Dwi Khonitan

meyelasraskan kegiatan yang ada di Desa

Bukit Langkap yang disesuaikan dengan keadaan dan permaahan yang ada. Kegiatan tersebut diharapkan dapat memperoleh keuantungan baik secara ekonomi dan soasial yang bermanfaat bagi masyarakat dan mendukung social entrepreneurship di Desa Bukit Langkap.

\section{Motivator}

Dalam menumbuhkan keinginan untuk melaksanakan kegiatan social entreprenurship masyarakat untuk meningkatkan kesejahteraanya ekonomi dan sosialnya, kepala Desa Bukit Langkap Bapak Sudarmin dengan bantuan Balai Penelitian Teknologi Pertanian Provinsi Kepulauan Riau melaksanakan kegiatan budidaya padi dengan jenis padi Inpari 30 dengan sistem tanam Tanpa Olah Tanamdan jajar legowo 5:1, dengan bimbingan terus menerus hasilnya sangat baik, sehingga mampu memotivasi masyarakat untuk melaksanakan kegiatan budidaya padi, lalu ketekunan dalam merawat hewan ternak berupa sapi bali juga mendorong masyarakat untuk merawat sapi balinya secara baik, pembenaran manajemen perkandangan, pakan, dan kesehatan juga saat ini sudah membaik dengan bantuan beberapa pihak terkait seperti petugas dari dinas kesehatan hewan ternak.

\section{d. Teladan}

Keberhasilan dari kegiatan social entrepreneuership di Desa Bukit Langkap tidak terlepas dari tokoh yang bisa menjadi teladan para masyarakat desa. Tokoh masyarakat yang menjadi teladan di Desa Bukit Langkap adalah Kiyai yaitu Bapak Syaidin dimana beliau berhasil melaksanakan panen pertama di Desa Bukit Langkap dengan dibantu kedelapan anaknya beliau menjadi sosok teladan para warga dalam melakukan penanaman padi. Padi yang berhasil dipanen di desa ini juga menjadi salah satu komoditi yang dijadikan peluang kepala desa untuk digunakan sebagai salah satu icon kegiatan social enterpreneurship selain pembangunan kandang koloni. Kegigihan kiyai desa ini juga ditiru para warga dalam kegiatan bertani.

Tantangan yang merupakan suatu masalah besar dalam masyarakat di Desa Bukit Langkap adalah belum optimalnya kemauan dan penyadaran masyarakat untuk mengembangkan lahan. Lahan yang dimiliki masayarakat belum menjadi lahan yang dapat menghasilkan profit maximalization padahal lahan tersebut merupakan opportunity cost yang dapat dimanfaatkan secara baik oleh masyarakat desa. Dalam penumbuhan kemauan dan penyadaran masyarakat ini tokoh masyarakat memberikan suatu teladan untuk beragribisnis dan berorientasi pada kegiatan sosial. Pemberian teladan ini 
Jurnal Pemikiran Sosiologi Volume 5 No. 2, 2018

Pemberdayaan Masyarakat Berbasis “Social Entrepreunership” Bidang Pertanian dan Peternakan: Studi Kasus

Desa Bukit Langkap, Kabupaten Linggau, Kepulauan Riau

Bekti Nur Utami, Dwi Khonitan

dilakukan oleh tokoh masyarakat di desa ini seperti pengolahan lahan pribadi dengan budidaya padi varietas inpari 30 dan menghasilkan beras yang mampu di pasarkan dengan label BUMDes dengan memperoleh laba yang digunakan sebesar 30\% untuk dana pengembangan lahan masyarakat lain yang belum dibuka dan diolah, setidaknya setiap satu KK memiliki tanah sebesar 1 hektar sampai 2 hektar yang belum dibuka dan diolah. Penyadaran yang dilakukan di desa ini berjalan dengan baik dan memperoleh respon yang baik pula antara lain: (a) masyarakat aktif dalam bergotong royong dalam mensukseskan kegiatan social enterpreneurship (b) masyarakat yang telah dibuka lahannya mau menyisakan 30\% keuntungan untuk dijadikan modal pengembangan (c) masyarakat yang telah mengikuti kegiatan ini mau untuk mengajak keluarga lain yang belum mengikuti kegiatan ini.

\section{Pengkapasitasan}

Pada tahapan ini pemberdayaan masyarakat di Desa Bukit Langkap dilakukan dengan cara pelatihan. Pelatihan diselenggarakan secara swadaya oleh tokoh masyarakat desa. Materi pelatihan adalah bidang pertanian dan peternakan. Di bidang pertanian dimulai dengan pembukaan lahan. Terkait kegiatan pembukaan lahan tersebut, diperlukan keterampilan pengoperasian alat dan mesin pertanian. Pelatihan di bidang peternakan adalah pembuatan pupuk organik dari kotoran ternak sapi. Hasil pembuatan pupuk organik digunakan untuk pemupukan lahan yang siap diolah.

Tahapan pengkapasitasan selanjutnya adalah dengan pembentukan struktur organisasi masyarakat desa dalam kegiatan social enterpreneurship. Struktur organisasi yang disusun didasarkan pada kemampuan leadership setiap posisi jabatan dalam organisasi. Penyusunan struktur organisasi di desa ini bertujuan untuk monitoring dan peyelarasan tugas dan fungsi pokok masingmasing anggota. Pembentukan organisasi dilakukan secara musyawarah mufakat dari masyarakat di desa. Kegiatan social enterpreneurship dapat berjalan dengan baik karena koordinasi yang baik antar elemen jabatan organisasi. Selain pembentukan organisasi di desa ini, masyarakat juga membuat aturan yang mengikat anggota terkait social enterpreneurship. Aturan yang digunakan merupakan aturan yang berasal dari kesepakatan bersama demi mencapai tujuan awal program. Sudarmin selaku kepala desa mengatakan "Adanya aturan ini sebagai pengontrol masyarakat sehingga teteap berjalan sesuai alurm aturan yang dibuat juga tidak memberatkan masyarakat karena turan itu bersumber dari kesepakatan mereka sendiri" Aturan tersebut dinamakan sebagai 
Jurnal Pemikiran Sosiologi Volume 5 No. 2, 2018

Pemberdayaan Masyarakat Berbasis “Social Entrepreunership” Bidang Pertanian dan Peternakan: Studi Kasus

Desa Bukit Langkap, Kabupaten Linggau, Kepulauan Riau

Bekti Nur Utami, Dwi Khonitan

"Aturan Pembagian Hasil Untuk Semua". Aturan ini digunakan untuk memberikan keadilan dalam pembagian manfaat sosial di masyarakat sehingga tidak ada salah satu pihak yang diuntungkan dan dirugikan dalam aturan program ini. Adapun keuntungan yang diberikan dalam hal pengkapasitasan ini :

(a) terbentuknya struktur organisasi yang jelas

(b) terciptanya pemikiran inovasi baru

(c) perubahan sikap leadership masyarakat

(d) penambahan wawasan masyarakat.

Adanya organisasi dan kegiatan pelatihan, masyarakat bisa membuat pembuatan pupuk organik melalui fermentasi dari kotoran ternak sapi. Pupuk organik hasil pengolahan selanjutnya dipasarkan melalui BUMDes dengan sistem pembagian keuntungan untuk kegiatan social enterpreneruship. Keuntungan hasil penjualan selanjutnya digunakan untuk kepentingan sosial yaitu pembukaan lahan dan pembangunan sarana desa seperti saluran irigasi dan jalan baik sebagai akses transportasi maupun akses menuju lahan.

\section{Pendayaan}

Social enterpreneurship di Desa Bukit Langkap, kepala desa memberikan otoritas kepada masyarakat untuk menjalankan aturan dengan baik. Otoritas pelaksanaan ini diberikan sesuai dengan kemampuan masyarakat sehingga masyarakat memiliki peluang yang besar untuk memaksimalkan social entrepreneurship yang dilaksanakannya. Bentuk otoritas tersebut adalah penggunaan dana dari laba BUMDes. Laba yang diperoleh dari BUMDes digunakan untuk social entrepreneurship di Desa Bukit Langkap. Selain penggunaan dana, otoritas tentang pengorganisasian juga diberikan secara penuh kepada masyarakat desa. Beberapa keuntungan pendayaan ini adalah (a) peluang keuntungan bisa disesuaikan dengan kebutuhan masyarakat (b) tidak adanya paksaan terhadap beberapa pihak (c) munculnya sikap bertanggung jawab atas pelaksanaan social enterpreneurship di Desa Bukit Langkap.

\section{Faktor pendukung dan Faktor Penghambat}

Keberhasilan pembedayaan masyarakat berbasis social enterpreneurship dibidang pertanian di Desa Bukit Langkap ditunjang oleh faktor pendukung dan penghambat.

\section{Faktor Pendukung}

Faktor pendukung sangat berperan untuk keberhasilan social enterpreneurship dalam pemberdayaan masyarakat di Desa Bukit Langkap. Faktor pendukung mampu memperkuat pelaksanaan social entrepreneurship. Terbukti dengan terlaksananya pembukaan lahan milik 
Jurnal Pemikiran Sosiologi Volume 5 No. 2, 2018

Pemberdayaan Masyarakat Berbasis “Social Entrepreunership” Bidang Pertanian dan Peternakan: Studi Kasus

Desa Bukit Langkap, Kabupaten Linggau, Kepulauan Riau

Bekti Nur Utami, Dwi Khonitan

masyarakat. Pada tahap awal, seluas 10

hektare lahan masyarakat telah berhasil dibuka. Lahan tersebut akan digunakan untuk persawahan dan pembutan kandang kelompok.

(a) Modal awal

Modal awal ini merupakan faktor pendukung awal dalam pelaksanaan kegiatan, melalui perhitungan cash flow setidaknya dalam kegiatan social entreprenurship modal awal akan segera kembali dan akan menguntungkan masyarakat karena pendanaan terus berlanjut melalui keuntungan bersaa sehingga selain ekonomi meningkat, infrastruktur yang menjadi kebutuhan bersama juga semakin berkembang dan layak digunakan bersama.

(b) Kerukunan masyarakat

Kerukunan metupakan kunci keberhasilan kegiatan bersama dengan adanya kerukunan masyarakat mampu meningkatkan motivasi dalam menjalankan program Social enterpreneurship karena terciptanya kesadaran untuk sukses bersama. Partisispasi aktif masyarakat pada kelompok tani dan ternak di Desa Bukit Langkap menjadikan power tersendiri dalam peningkatan kesadaran masyarakat sehingga istilah bersama kerja dalam kerjasama di desa ini bisa terwujud. (c) Tokoh masyarakat yang berdikari

Tokoh masyarakat di desa Bukit Langkap sangat berperan baik dalam pemberian motivasi, meringankan modal awal , pemberian ilmu terhadap masyarakat, serta menjadi agen of change dalam meningkatkan kemandirian dan peningkatan finansial masyarakat Desa Bukit Langkap.

\section{Faktor Penghambat}

Selain faktor pendukung dalam pemberdayaan masyarakat di Desa Bukit Langkap adapula faktor yang menjadi penghambat social entrepreneurship yang dijalankan oleh masyarakat. Faktor pendukung tersebut adalah :

(a) Rendahnya leadership

Jiwa leadership masyarakat di Bukit Langkap masih rendah. Hal ini terlihat, karakter masyarakat yang belum dewasa dalam menjalankan social leadership. Masayakat belum mampu malaksanakan sendiri social entrepreneurship. Pelaksanaan social leadership didorong oleh tokoh nasyarakat di Desa Bukit Langkap tersebut.

(b) Kurang siapnya sumber daya manusia Sumberdaya manusia di Desa Bukit Langkap belum memahami opportunity cost dari social entrepreneurship. Hal ini terlihat dari 
Jurnal Pemikiran Sosiologi Volume 5 No. 2, 2018

Pemberdayaan Masyarakat Berbasis “Social Entrepreunership” Bidang Pertanian dan Peternakan: Studi Kasus

Desa Bukit Langkap, Kabupaten Linggau, Kepulauan Riau

Bekti Nur Utami, Dwi Khonitan

masyarakat yang tidak tertib dalam penjadwalan kegiatan rutin dan memilih melaksanakan kegiatan pribadi diluar pekerjaan mereka.

(b) masyarakat yang telah dibuka lahannya mau menyisakan 30\% keuntungan untuk dijadikan modal pengembangan

(c) Kurangnya pengetahuan dan keterampilan teknis di bidang pertanian dan peternakan.

Masyarakat Desa Bukit Langkap yang merupakan masyarakat dari program transmigrasi mempunyai latar belakang yang beranekaragam. Masyarakat belum mempunyai pengetahuan dan ketrampilan teknis di bidang pertanian dan peternakan, sehingga kegiatan kadang kala terkendala karena kurangnya kesiapan teknis pada setiap anggota pelaksanaan program.

\section{E. Kesimpulan}

Pemberdayaan masyarakat yang berbasis social enterpreneurship di desa Bukit Langkap bisa dinilai dari proses pemberdayaan masyarakat. Proses pemberdayaan tersebut antara lain dijabarkan sebagai berikut. Pertama, penyadaran yang dilakukan di desa ini berjalan dengan baik dan memperoleh respon yang baik pula diantaranya:

(a) masyarakat aktif dalam bergotong royong dalam mensukseskan kegiatan social enterpreneurship

Kedua, pengkapasitasan. Adapun keuntungan yang diberikan dalam hal pengkapasitasan ini: (a) Terbentuknya sistematika organisasi yang jelas

(b) terciptanya pemikiran inovasi baru

(c) perubahan sikap leadership masyarakat (d) penambahan wawasan masyarakat.

Ketiga, pendayaan dalam program Social Enterpreneurship di desa Bukit Langkap masyarakat diberikan otoritas dari kepala desa untuk menjalankan aturannya dengan baik. Beberapa keuntungan pendayaan ini adalah:

(a) peluang keuntungan bisa disesuaikan dengan kebutuhan masyarakat

(b) tidak adanya paksaan terhadap beberapa pihak

(c) munculnya sikap bertanggung jawab atas pelaksanaan program Social Enterpreneurship. 
Jurnal Pemikiran Sosiologi Volume 5 No. 2, 2018

Pemberdayaan Masyarakat Berbasis “Social Entrepreunership” Bidang Pertanian dan Peternakan: Studi Kasus

Desa Bukit Langkap, Kabupaten Linggau, Kepulauan Riau

Bekti Nur Utami, Dwi Khonitan

Sementara itu penelitian juga

Daftar Pustaka

mengidentifikasi faktor pendukung dan penghambat dalam pelaksanaan social entrepreunership di Desa Bukit Langkap. Faktor pendukung dalam pemberdayaan masyarakat berbasis social enterpreneurship antara lain:

(a) Modal awal

(b) Kerukunan masyarakat

(c) tokoh masyarakat yang berdikari.

Adapun faktor penghambat antara lain:

(a) kurangnya pemahaman masyarakat tentang opportunity cost dari program ini

(b) belum ratanya jiwa leadership dikalangan masyarakat.

Meskipun masyarakat desa Bukit Langkap adalah kelompok transmigran, akan tetapi dalam kenyataannya dalam pelaksanaan social entrepreunership di bidang pertanian dan peternakan meraka belum cukup terampil dikarenakan kendala teknis maupun dalam penguasaan pengetahuan dan ketrampilan termasuk kendala sosial seperti kesenjangan antara tokoh masyarakat dengan warga desa (para petani dan peternak).

Ainur , R dan Hartati. (2007) Petunjuk Teknis Perkandangan Sapi Potong. Grati, Pusat Penelitian dan Pengembangan Peternakan.

Anonim. (2017) Data Morfologi Desa Bukit Langkap 2017. Lingga.

Bramada W.P, Handian. (2014). Pemanfaatan Lahan Tidur Untuk Penggemukan Sapi. Bogor. Risalah Kebijakan Pertanian dan Lingkungan Vol. 1 No. 2 Agustus 2014: 92-96 ISSN : 23556226.

Creswell, J.W. (1998). Qualitative inquiry and research design: Choosing among five traditions. Thousand Oaks, CA:Sage.

Certo, T. S., and Miller, T. Social entrepreneurship: Key issues and concepts. U.S.A. Business Horizons (2008) 51, 267-271

Mardikanto, Totok dan Poerwoko Soebiato. (2013) Pemberdayaan Masyarakat Dalam Presektif Kebijakan Publik. Bandung, Alfabeta.

Pranadji, Tri. 2009. Penguatan Kelembagaan Gotong Royong dalam Perspektif Sosio Budaya Bangsa. Bogor. Jurnal Forum Penelitian Agro Ekonomi, IPB.Volume 27 No. 1, Juli 2009.

Rozikin, M. , Hermawan, dan Astuti, L.I. Tanpa Tahun. Pemberdayaan Masya rakat Dalam Pembangunan Pertanian Berkelanjutan. Malang, Jurnal Administrasi Publik (JAP), Vol. 3, No. 11.

Strauss, A., \& Corbin, J. (1998) . Basic of qualitative research (Edisi ke-2). Newburry Park, CA:Sage.

Undang-Undang Republik Indonesia Nomor 19 Tahun 2013 Tentang Perlindungan dan Pemberdayaan Petani. Jakarta, 
Jurnal Pemikiran Sosiologi Volume 5 No. 2, 2018

Pemberdayaan Masyarakat Berbasis “Social Entrepreunership” Bidang Pertanian dan Peternakan: Studi Kasus

Desa Bukit Langkap, Kabupaten Linggau, Kepulauan Riau

Bekti Nur Utami, Dwi Khonitan

Menteri Hukum dan Hak Asasi

Manusia Republik Indonesia.

Undang, Santosa. (2011) Mengeola

Peternakan Sapi Secara Profesional.

Jakarta, Penerbit Swadaya.

Wrihatnolo, Randy $\mathrm{R}$ dan Riant Nugroho Dwidjowijoto. (2007) Manajemen Pemberdayaan: Sebuah Pengantar dan Panduan untuk Pemberdayaan Masyarakat. Jakarta, Media Komputin. 